\title{
LINC LEVEL 2
}

Brod, S., \& Frankel, I. (1992). Canadian crossroads 2. Student Book. 132 pages. Sample, B. Teacher's Book. 131 pages. Fuchs, M., Brod, S., \& Frankel, I. Multilevel Activity and Resource Package. 246 pages. Don Mills, Ont.: Oxford University Press. Student book $\$ 15.95$; Activity/Resource package $\$ 80.00$; Teacher's book $\$ 20.95$; Audiocassettes $\$ 65.00$.

general language study; audiocassettes; illustrations; exercises; forms; grammar; answers; tapescripts; life skills

Each level includes a student book, teacher's book, multilevel activity and resource package and audiocassettes. The student book contains 10 units, covering a variety of life skill topics (e.g. housing, health, food, transportation, employment). All skills are integrated in each unit, along with new grammatical structures. At the end of each unit are Progress Checks and a Memo to the teacher. At the beginning of the student book is a section of step-by-step procedures covering the majority of exercise types. Grammar summaries and tapescripts are found at the end of the student book. The teacher's book includes reproducible versions of the first-page illustrations, instructions, suggestions, pronunciation exercises, cross-references to exercises in the multilevel activity and resource package and cross-references to vocabulary pages in The New Oxford Picture Dictionary. Competency checklists are found at the back of the teacher's book. The Multilevel Activity and Resource Package contains reproducible workbook pages, picture cards, word cards, game boards and interactive activities. Worksheets come in two levels (A and B). Teacher's Notes are included for each unit. 
Invergarry Learning Centre. (1992). A war every day. Surrey, B.C.: Invergarry Learning Centre. 4 pages. $\$ 1.00$.

ESL literacy

The author, an ESL learner, writes about her life in Laos, and the hardships she went through before arriving in Canada.

Invergarry Learning Centre. (1992). For a new beginning. Surrey, B.C.: Invergarry Learning Centre. 42 pages. $\$ 1.00$.

ESL literacy

The authors, who were ESL learners, have written stories about different aspects of their lives in five countries where they previously lived: India, Vietnam, Guatemala, Colombia and India.

Invergarry Learning Centre. (1992). From India to Canada. Surrey, B.C.: Invergarry Learning Centre. 25 pages. $\$ 1.00$.

ESL literacy

Tony Basra, a new immigrant in Canada, has written a collection of stories, covering a variety of topics. His topics range from personal feelings such as joy, excitement and sadness to descriptions of Indian weddings, food and the Caste System.

Invergarry Learning Centre. (1992). Hea's many homes. Surrey, B.C.: Invergarry Learning Centre. 40 pages. $\$ 1.00$.

ESL literacy; photographs

The author writes about his life, starting in Cambodia in 1939 and arriving in Canada in 1990, and the many homes he and his family had in between.

TESL CANADA JOURNAL/REVUE TESL DU CANADA 
Invergarry Learning Centre. (1992). Rani's story. Surrey, B.C.: Invergarry Learning Centre. 19 pages. $\$ 1.00$.

ESL literacy

The nine stories written by Rani focus on her personal feelings of India. Her stories include memories of her school and village in India, a story and movie that she liked and her daily schedule.

Invergarry Learning Centre. (1992). Three by four. Surrey, B.C.: Invergarry Learning Centre. 37 pages. $\$ 1.00$.

ESL literacy; beginner to intermediate proficiency

The book was written and produced by four students, each of whom wrote three stories and/or poems on personal topics.

North York Board of Education. (1991). Moving on! and Student Workbook: Moving on!. North York: North York Board of Education. $41+40$ pages. $\$ 10.00$.

ESL literacy; illustrations; pictures; exercises

Adult students in literacy programs wrote, edited and revised their stories with the help of their instructor where necessary. Various themes are represented in the stories, e.g. adventures, experiences and personal thoughts. The student workbook consists of nine stories, each story followed by a variety of written activities. Activities in the student book can be reproduced for classroom use.

Rabinowitz, M. (1986). Having an operation: An ESL workbook. Community Survival Skills Series. Vancouver: Vancouver Community College. 67 pages. $\$ 7.50$

life skills and community resources; illustrations 
Vocabulary for describing one's health, filling in hospital forms, and understanding what doctors and nurses are doing and saying in the hospital during pre- and post-surgery is given in dialogues and in sentence completion, short answer, and matching exercises.

Reid, J., Applebaum, S., Hom, K.L., Vane, J., \& Yin, M. (n.d.). Food and restaurant. 35 pages. Shopping. 43 pages. Transportation and community living. 37 pages. Toronto: Toronto Board of Education. $\$ 5.00$.

ESL literacy; life skills and community resources; vocabulary; series; regional; illustration; hand-lettered text

The exercises in these 3 booklets encourage development of reading and writing skills through tracing of letters, matching words to pictures, and language experience stories that create a "word bank". Exercises are organized by topic, not difficulty. The food and restaurant booklet focuses on names of food items and prices. The booklet on shopping introduces vocabulary and symbols, such as care labels on clothing and instructions on prescriptions, as well as numbers, days and time. Exercises in the transportation and community living booklet focus on using public transportation in Toronto and area, and on other public services such as libraries and Ontario health services.

Reid, J., Taborek, E., \& Leung, F. (n.d.). My neighborhood. Toronto: Toronto Board of Education. 55 pages. $\$ 5.00$.

life skills and community resources; regional; illustrations; handlettered text

For adult students in a beginning English program, this booklet focuses on language used to describe various aspects of community life, organized into sections called: where do you live?, housing in my neighborhood, people working in my 
community, and I go to these places. Brief notes to the instructor summarize the content of each section and suggest topics for discussion. Exercises and activities are based on residence in Toronto and areas. Black and white photos and hand-drawn maps appear throughout.

Reid, J., Taborek, E., \& Wood, D. (n.d.). Holidays, wages, and the dental plan: Communication activities for the ESL in the workplace program. Toronto: Toronto Board of Education. 61 pages. $\$ 5.00$.

ESL for the workplace; ESL literacy; regional; appendices

Eighteen exercises are based on information about Ontario's labour laws and dental care coverage. Each exercise is prefaced by a list of objectives and notes to the instructor about method of presentation. Students' exercises include fill-in-the-blank conversations, reading comprehension questions, and discussion questions. Appendices give specific information about Ontario.

Reid, J., Taborek, E., \& Wood, D. (n.d.). Talking about transportation: Communication activities for the ESL classroom. Toronto: Toronto Board of Education. 53 pages. $\$ 5.00$.

life skills and community resources; ESL literacy; speaking/ conversation; regional; illustrations; appendices

Focusing on signs in the Toronto subway system, as well as on hand-drawn maps and fare information, students learn how to use the subway. Black and white photos and language used in giving and receiving directions are key elements in the exercises. Each lesson is prefaced by a list of objectives as well as instructor notes on methods and discussion topics.

Sacco, M. (1976). Has/had: The present perfect and simple past.

Ottawa: Supply and Services Canada. 60 pages. $\$ 2.75$. 
grammar; illustrations; exercises; film/videocassette

The booklet introduces the present perfect, provides a variety of exercises and contrasts it to the past tense and present perfect continuous verb forms. The booklet is designed to be used after the film/videocassette Has/had which is available from the National Film Board of Canada.

Toronto Board of Education. (1984). Our lives. Toronto: Toronto Board of Education. 48 pages. $\$ 8.00$

ESL literacy; speaking/conversation;life stories; regional; illustrations

Portuguese women in adult ESL classes in Toronto dictated these stories to their teachers and used them in classes to develop their English language proficiency. Topics centre on life in Canada, especially work and family, with an introductory section about Portugal. Following each reading passage are questions and exercises that expand on basic themes.

Toronto Board of Education. (1990). More than just Chinese Food... Toronto: Toronto Board of Education. 41 pages. $\$ 13.00$

ESL literacy; speaking/conversation; illustrations

This book consists of writing by adult ESL learners of Chinese origin. The book is organized around four basic themes: family, education, social customs, and festivals. Each short text is accompanied by a set of questions for oral discussion and group work activities. 
Wall, N. (Ed.). (1985). We make the clothes. Toronto: Learnx Press. 24 pages. $\$ 8.00$.

English for work; ESL literacy; vocabulary; speaking/ conversation; illustrations

A picture story follows the steps for producing an article of clothing in a garment factory in Toronto. The story is divided into sections that correspond to the division of labour in the factory: pattern-making, the computer room, the cutting room, the sample room, the shop floor, and the shipping room. Jobrelated vocabulary is used in context, describing the activities shown in the pictures. 